\title{
The Effect of Pre-Procedure Anxiety on Pain Perception During First Session of Shock Wave Lithotripsy
}

\author{
İlk Seans Şok Dalga Litotripsi Öncesi Anksiyetenin Işlem Esnasında Ağrı \\ Üzerine Etkisi
}

\author{
Ömer Yılmaz, Fırat Saraçoğlu, Temuçin Şenkul, Murat Zor, Hasan Soydan, Ercan Malkoç, Ferhat Ateş \\ Gülhane Military Medical Academy, Haydarpaşa Training and Research Hospital, Clinic of Urology, İstanbul, Turkey
}

\section{What's known on the subject? and What does the study add?}

It is known that shock wave lithotripsy is a painful procedure for some patients as much that they cannot complete. We evaluated the effect of patient's anxiety on pain during shock wave lithotripsy and found that it is effective.

\begin{abstract}
Introduction

Although shock wave lithotripsy (SWL) is a common noninvasive procedure, it can be very painful and a serious source of anxiety which may affect pain perception. The aim of this study was to evaluate the association between patient's anxiety and SWL-related pain.

\section{Materials and Methods}

A total of 54 patients, who underwent the first session of SWL treatment between January and April 2014 due to a single renal pelvic stone with a diameter less than $20 \mathrm{~mm}$, were included in the study. All patients were particularly informed about the procedure and, then, the validated Hospital Anxiety and Depression scale was administered in order to identify the anxiety level before the procedure. All relevant data, such as age, sex, stone size, body mass index (BMI), anxiety score, visual analog scale (VAS) score, skin-to-stone distance, and total energy were recorded.
\end{abstract}

\section{Results}

The mean age of the study population was $41.11 \pm 16.35$ years. The mean stone size, anxiety level before procedure, VAS score during SWL, BMI, skin-to-stone distance and energy level were $10.69 \pm 4.75 \mathrm{~mm}(5-20$ $\mathrm{mm}), 5.2 \pm 3.87 ; 6.5 \pm 2.46 ; 25.77 \pm 4.16 ; 7.23 \pm 2.10 \mathrm{~cm} ; 56.53 \pm 16.74$ joule, respectively. Anxiety prior to procedure, energy level and the number of total shock wave had a significant effect on VAS score $(p<0.05)$. Sex stone size, BMI and skin-to-stone distance did not significantly affect the VAS scores $(p>0.05)$.

\section{Conclusion}

According to our results, reducing patient anxiety, if any, can provide some additional pain control during SWL procedure and can improve patient compliance.

\section{Keywords}

Shock wave lithotripsy, pain, anxiety
öZ

Amaç

Sok dalga litotripsi, üriner sistem taş hastalığı tedavisinde kullanılan invazif olmayan yöntemlerin başında gelmesine rağmen oluşturduğu ağrı ve anksiyete nedeni ile bazı hastalar tarafından tolere edilememektedir. Bu çalışmada şok dalga litotripsi öncesinde hastada oluşan anksiyetenin işlem esnasındaki ağrıya etkisi araştırıldı.

\section{Gereç ve Yöntem}

Çalışmaya Ocak 2014-Nisan 2014 tarihleri arasında 20 mm'den küçük tek böbrek pelvis taşı nedeni ile ilk defa şok dalga litotripsi tedavisi yapılan 54 hasta dahil edildi. İşlem öncesinde tüm hastalar şok dalga litotripsi hakkında detaylı olarak bilgilendirildikten sonra valide edilmiş Hastane Anksiyete Depresyon ölçeği doldurtularak anksiyete seviyeleri ölçüldü. İşlemden hemen sonra ise şok dalga litotripsi süresince hissettikleri ağrı vizüel ağrı skalası doldurtularak değerlendirildi. Ayrıca yaș, cinsiyet, taş boyutu, vücut kitle indeksi (VKi), deri-taş mesafesi, uygulanan toplam enerji miktarı da kayıt altına alınarak tüm bu değișkenlerin ağrı ile ilișkisi araştırıldı.

Bulgular

Kırk beş $(83,3 \%)$ erkek $9(16,7 \%)$ kadın toplam 54 hastanın ortalama yaşı $41,11 \pm 16,35$ idi. Ortalama tas boyutu, işlem öncesi anksiyete seviyesi, işlem esnasındaki ağrı skoru, VKi, deri-taş mesafesi, şok dalga litotripsi için uygulanan toplam enerji seviyesi sıra ile $10,69 \pm 4,75 \mathrm{~mm}, 5,2 \pm 3,87$; $6,5 \pm 2,46 ; 25,77 \pm 4,16 ; 7,23 \pm 2,10 \mathrm{~cm} ; 56,53 \pm 16,74$ jul idi. İşlem öncesi anksiyete seviyesi, toplam uygulanan enerji ve şok dalga sayısı ağrı skorları üzerine istatistiksel olarak anlamlı derecede etkili bulundu $(p<0,05)$. Yaş, cinsiyet, taş boyutu, VKi, deri-taş mesafesinin ise ağrı skorlarına etkisi istatistiksel anlamlı seviyede bulunmadı $(p>0,05)$.

Sonuç

Elde ettiğimiz sonuçlara göre ișlem öncesi anksiyete şok dalga litotripsi esnasında ağrıyı etkileyen faktörlerden birisidir ve anksiyeteye yönelik alınacak önlemler ağrı kontrolüne, dolayısı ile hasta uyumuna katkı sağlayabilir.

Anahtar Kelimeler

Şok dalga litotripsi, ağrı, anksiyete

\section{Correspondence}

Ömer Yılmaz MD, Gülhane Military Medical Academy, Haydarpaşa Training and Research Hospital, Clinic of Urology, İstanbul, Turkey

Phone: +90 5303226834 E-mail: dr_omeryilmaz@yahoo.com Received: 13.12.2015 Accepted: 16.02.2016 


\section{Introduction}

In the last decade, open surgery was almost completely replaced by shock wave lithotripsy (SWL) and endourologic techniques, such as ureterorenoscopy and percutaneous nephrolithotomy in the treatment of urinary stone disease (1). SWL offers important advantages for the treatment of renal and ureteral stones. In particular, it is noninvasive, is readily performed on an out-patient basis and can be very effective in treating solitary uncomplicated stones (2). However, despite the advantages of SWL, pain resulting from shock wave treatment is still commonly bothersome to the patients. This may be one of the reasons for some patients to hesitate in preferring SWL treatment (3). At the same time, it is known that SWL procedure can cause significant anxiety influencing the success of the SWL treatment by decreasing patient compliance (4). Several clinical factors, such as sex, body mass index (BMI), delivery of shock wave energy for stone fragmentation and stone location, have been determined as predictive factors for SWL-related pain $(5,6)$. However, little clinical data are available regarding patient pre-procedure anxiety that may affect the pain perception during SWL. The aim of this study was to evaluate the association between patient anxiety and SWL-related pain.

\section{Materials and Methods}

After receiving local ethics committee approval and patient informed consent, a total of 54 patients, who underwent the first session of SWL treatment between January and April 2014 due to a single renal stone measuring less than $20 \mathrm{~mm}$ in diameter and located in the renal pelvis, were included in the study. All diagnoses and radiologic calculations were performed with non-contrast computed tomography and intravenous pyelography. There was not any bone superposition to stones. Treatment decision for SWL was made according to stone size, patient preference and anatomical convenience, such as suitable infundibulopelvic angle, suitable skinto-stone distance less than $10 \mathrm{~cm}$ with no obstruction in the urinary system. Patients who had contraindications for SWL treatment, such as active urinary tract infection and bleeding disorders were excluded from the study. Single urologist elaborated the procedure and then the patient filled the anxiety section of the validated Hospital Anxiety and Depression scale $(A / 0-21)(7,8)$ while waiting for the procedure in order to identify anxiety level just before the procedure in the waiting room at the SWL section. Intramuscular injection of $75 \mathrm{mg}$ diclofenac sodium was performed for pain relief thirty minutes before SWL. All patients were treated with Lithoskop ${ }^{\odot}$ SWL device (Siemens AG, Munich, Germany), with a maximum of 70 joule energy at 90 shocks per minute frequency up to 3000 shock waves. Immediately after the procedure, while patients were on the table, the degree of pain due to SWL was evaluated by using a 10-point visual analogue scale (VAS/010). All relevant data, such as age, sex, stone size, BMI, anxiety score, VAS score, were analysed by dividing the patients into three groups as low (0-3), intermediate (4-6) and high (8 and above), and total energy level of the lithotripter, skin-to-stone distance, and the number of the total shock wave were recorded. We performed statistical analysis in order to evaluate the effect of anxiety on pain perception during SWL by using all these data.

The statistical data were analyzed by using the Statistical Package for Social Sciences (SPSS ${ }^{\text {тм }}$, Chicago, IL, USA) version 16.0 for Windows. All values were expressed as mean \pm standard deviation. The differences between means were analyzed by using the Mann-Whitney $U$ test, Pearson correlation coefficient, chi-square test. Multivariate analysis was done at $95 \%$ confidence interval. A p value of less than 0.05 was considered statistically significant.

\section{Results}

The mean age of the patients [45 men (83.3\%) and 9 women (16.7\%)] was $41.11 \pm 16.35$ years. The mean stone size was $10.69 \pm 4.75 \mathrm{~mm}$ (5$20 \mathrm{~mm}$ ). The mean anxiety level before the procedure was $5.2 \pm 3.87$ and the mean VAS score during SWL was 6.5 \pm 2.46 . The mean BMI was $25.77 \pm 4.16$, skin-to-stone distance - $7.23 \pm 2.10 \mathrm{~cm}$, energy level $-56.53 \pm 16.74$ joule, and the mean shock wave number was $2713.48 \pm 457.34$ (Table 1). There was no difference in anxiety levels and VAS scores between male and female patients (Table 2). We found statistically significant difference between anxiety prior to procedure and VAS score (Table 3). The patients who had more anxiety felt more pain during the procedure. The other correlations on VAS score were the energy level $(r=0.644, p=0.002)$ and the total number of shock waves ( $r=0.605, p=0.005)$. Any negative effect of stone size on VAS scores could not be pointed $(r=0.018, p=0.896)$. BMl and skin-tostone distance also did not affect VAS scores significantly $(r=0.203$, $p=0.505$ and $r=0.147, p=0.632$, respectively) (Table 4). The variables (pre-procedure anxiety, energy level and number of session) were analysed by using multivariate analysis to determine any independent factor affecting VAS score, but the result could not reach statistically significant level $(p=0.238)$.

\section{Discussion}

Advances in technology have changed the treatment strategies of urinary stone disease. In the recent era, minimal invasive techniques are getting more and more popular in all over the world (1). Definitely, SWL is the first choice among these approaches for suitable small kidney and proximal ureteral stones due to its low complication rate and non-invasive nature (9). Although it is known that SWL does not require general anesthesia, sometimes SWL is a painful procedure for many patients resulting in procedure withdrawal (3). Although there are many studies evaluating SWL-related pain and its relief, there are few studies focusing specifically on the patient anxiety and its effect on pain perception during the first SWL session. Thus, we performed this

\begin{tabular}{|l|l|l|}
\hline \multicolumn{2}{|l|}{ Table 1. Patient's data } \\
\hline \multirow{2}{*}{ Sex } & Female & 9 \\
\cline { 2 - 3 } & Male & 45 \\
\hline Age & $41.11 \pm 16.35$ \\
\hline Stone size $(\mathrm{mm})$ & $10.69 \pm 4.75$ \\
\hline BMI & $25.77 \pm 4.16$ \\
\hline Skin-stone distance (cm) & $7.23 \pm 2.10$ \\
\hline VAS score & $6.5 \pm 2.46$ \\
\hline Anxiety score & $5.2 \pm 3.87$ \\
\hline Energy (joule) & $56.53 \pm 16.74$ \\
\hline Total shock wave number & $2713.48 \pm 457.34$ \\
\hline BMI: Body mass index, VAS: Visual analogue scale \\
\hline
\end{tabular}


Table 2. Analysis of anxiety level and visual analogue scale score according to sex

\begin{tabular}{|l|l|l|l|}
\hline \multirow{2}{|l|}{ Sex } & $\begin{array}{l}\text { Anxiety } \\
\text { score }\end{array}$ & VAS score \\
\hline \multirow{3}{*}{ Male $(n=45)$} & Mean & 5.29 & 6.44 \\
\hline \multirow{3}{*}{ Female $(n=9)$} & SD & 4.01 & 2.52 \\
\hline$p$ & Mean & 4.78 & 6.78 \\
\cline { 2 - 4 } & SD & 3.23 & 2.22 \\
\hline $\begin{array}{l}\text { No statistically difference was achieved (p>0.05), SD: Standard deviation, } \\
\text { VAS: Visual analogue scale }\end{array}$ & 0.90 & 0.87 \\
\hline
\end{tabular}

Tablo 3. Analysis of pre-procedure anxiety level according to visual analogue scale groups

\begin{tabular}{|l|l|}
\hline Mean VAS score & Mean pre-procedure anxiety level \\
\hline Low $(0-3) \rightarrow 2.33 \pm 1.5$ & $3.89 \pm 5.58$ \\
\hline Intermediate (4-7) $\rightarrow 5.95 \pm 0.95$ & $4.73 \pm 3.48$ \\
\hline High (8 and above) $\rightarrow 8.65 \pm 0.78$ & $6.17 \pm 3.37$ \\
\hline & $p$ \\
\hline Low $\leftrightarrow$ intermediate & 0.167 \\
\hline Intermediate $\leftrightarrow$ high & 0.118 \\
\hline Low $\leftrightarrow$ high & $0.022^{*}$ \\
\hline${ }^{*}$ Statistically significant, VAS: Visual analogue scale \\
\hline
\end{tabular}

Table 4. Correlation analysis results of possible factors that may influence visual analogue scale

\begin{tabular}{|l|l|}
\hline Variables & VAS \\
\hline Anxiety score & $\begin{array}{l}r=0.619 \\
\mathrm{p}=0.024^{*}\end{array}$ \\
\hline Energy level & $\begin{array}{l}\mathrm{r}=0.644 \\
\mathrm{p}=0.002^{*}\end{array}$ \\
\hline Total shock wave number & $\begin{array}{l}\mathrm{r}=0.605 \\
\mathrm{p}=0.005^{*}\end{array}$ \\
\hline BMI & $\begin{array}{l}\mathrm{r}=0.203 \\
\mathrm{p}=0.505\end{array}$ \\
\hline Skin to stone distance & $\mathrm{r}=0.147$ \\
& $\mathrm{p}=0.632$ \\
\hline Stone size & $\mathrm{r}=0.018$ \\
& $\mathrm{p}=0.896$ \\
\hline $\begin{array}{l}\text { * } p<0.05 \text { was deemed statistically significant, VAS: Visual analogue scale, BMI: Body } \\
\text { mass index }\end{array}$
\end{tabular}

study in order to evaluate the effect of anxiety prior to first SWL session on pain perception. On the other hand, it can be easily hypothesized that patient anxiety may also contribute to procedural pain perception.

Contrary to previous studies, we were not able to demonstrate any statistically significant difference between men and women in terms of prior anxiety and VAS scores ( 5.29 vs. $4.78, p=0.90$ and 6.44 vs. 6.78 , $p=0.87)(10,11)$. However, the number of female patients included in the study was very small and we concluded that it may not be enough to make a certain decision and a generalization.

The most important result of our study was the positive correlation between the patient's pre-procedural anxiety and pain perception.
The increased anxiety level made the procedure more painful and this result was statistically significant alike with Vergnolles' results (12). Our results suggest that pretreatment evaluation of anxiety level may change the pain control protocol to be applied to the patients, e.g., additional anxiolytic treatment prior to the procedure can help better pain control.

In our study, increased level of shock wave energy and the total number of shock waves significantly increased the pain perception similar with that in the literature (13). It was an expected result since the main traumatic factor is energy applied to stone and tissues.

Similar to the results of a study by Vergnolles et al. (12), but contrary to that of Tailly et al. (14), no significant correlation was observed between stone size and pain perception. Tailly et al. (14) concluded that smaller renal stones were associated with a higher analgesic requirement, explained by a higher proportion of the energy absorbed by the surrounding renal parenchyma and not by the stone itself. We minimized the parenchymal trauma by frequently checking the focus if it was on the stone. This strategy may explain the difference between our results and that of Tailly et al. (14) BMI and skin-to-stone distance was relevant as expected. Their effect on VAS score was not statistically significant in our study contrary to the study by Bach et al. (15). The reason might be that there was no significant difference between the body weight of our patients. If this study compared slim and obese patients, the results might have been different.

One limitation of our study is that we did not evaluate the SWL time for each patient and its effect on VAS scores. Additionally, we did not evaluate the hardness of the stone which may also affect the procedure time. Although all patients had the same SWL protocol starting and increasing with similar energy level, the overall procedure time could have been different for each patient due to different stone fragmentation time and, also increased duration of procedure could affect pain perception.

\section{Conclusion}

Despite its noninvasive nature, SWL is a painful procedure and it may cause anxiety that increases pain perception and decreases patient compliance. According to our results, reducing patient anxiety, if any, can provide some additional pain control during SWL procedure and may increase the success of SWL.

\section{Ethics}

Ethics Committee Approval: The study were approved by the Gülhane Military Medical Academy, Haydarpaşa Training Hospital of Local Ethics Committee, Informed Consent: Consent form was filled out by all participants. Peer-review: Internal peer-reviewed.

\section{Authorship Contributions}

Surgical and Medical Practices: Fırat Saraçoğlu, Concept: Ömer Yılmaz, Design: Hasan Soydan, Data Collection or Processing: Murat Zor, Analysis or Interpretation: Ferhat Ateş, Literature Search: Ercan Malkoç, Writing: Ömer Yılmaz, Temuçin Şenkul. Conflict of Interest: No conflict of interest was declared by the authors, Financial Disclosure: The authors declared that this study has received no financial support. 


\section{References}

1. Rassweiler J, Rassweiler MC, Frede T, Alken P. Extracorporeal shock wave lithotripsy: An opinion on its future. Indian J Urol 2014;30:73-79.

2. Lingeman JE, McAteer JA, Gnessin E, Evan AP. Shock wave lithotripsy: advances in technology and technique. Nat Rev Urol 2009;6:660-670.

3. Kang JH, Lee SW, Moon SH, Sung HH, Choo SH, Han DH. Relationship between patient position and pain severity during shock wave lithotripsy for renal stones with the MODULITH SLX-F2 lithotripter: a matched casecontrol study. Korean J Urol 2013;54:531-535.

4. Ngee-Ming G, Tamsin D, Rai BP, Somani BK. Complementary approaches to decreasing discomfort during shockwave lithotripsy (SWL). Urolithiasis 2014;42:189-193.

5. Tokgöz $H$, Hanci $V$, Türksoy 0 , Erol B, Akduman B, Mungan NA. Pain perception during shock wave lithotripsy: does it correlate with patient and stone characteristics? J Chin Med Assoc 2010;73:477-482.

6. Berwin JT, El-Husseiny T, Papatsoris AG, Hajdinjak T, Masood J, Buchholz N. Pain in extracorporeal shock wave lithotripsy. Urol Res 2009;37:51-53.

7. Bjelland I, Dahl AA, Haug TT, Neckelmann D. The validity of the hospital anxiety and depression scale. An updated literature review. J Psychosom Res 2002;52:69-77.
8. Aydemir Ö, Güvenir T, Küey L, Kültür S. The validity and reliability of the Turkish version of the hospital anxiety and depression scale. Türk Psikiyatri Dergisi 1977;8:280-287.

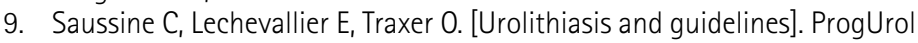
2008;18:841-843.

10. Ng CF, Thompson T, Tolley D. Characteristics and treatment outcome of patients requiring additional intravenous analgesia during extracorporeal shockwave lithotripsy with Dornier compact delta lithotriptor. Int Urol Nephrol 2007;39:731-735.

11. Robert M, Lanfrey P, Rey G, Guiter J, Navratil H. Analgesia in piezoelectric SWL: comparative study of kidney and upper ureter treatments. I Endourol 1999;13:391-395.

12. Vergnolles $M$, Wallerand $H$, Gadrat $F$, Maurice-Tison $S$, Deti $E$, Ballanger $P$, Ferriere JM, Robert G. Predictive risk factors for pain during extracorporeal shockwave lithotripsy. J Endourol 2009;23:2021-2027.

13. Salinas AS, Lorenzo-Romero J, Segura M, Calero MR, Hernández-Millán I, Martínez-Martín M, Virseda JA. Factors determining analgesic and sedative drug requirements during extracorporeal shock wave lithotripsy. Urol Int 1999;68:92-101.

14. Tailly GG, Marcelo JB, Schneider IA, Byttebier G, Daems K. Patient-controlled analgesia during SWL treatments. J Endourol 2001;15:465-471.

15. Bach C, Zaman F, Kachrilas S, Kumar P, BuchholzN, Masood J. Drugs for pain management in shock wave lithotripsy. Pain Res Treat 2011;2011:259426. 